\title{
Dinamika Konflik Antar Etnis Dayak dan Etnis Madura di Samalantan Kalimantan Barat
}

\section{Sutanti}

Ilmu Pemerintahan, Universitas Sultan Ageng Tirtayasa Sutianti2712@gmail.com
E-ISSN (2721-0642)

Recieved:

March 262020

Revised:

April 112020

Accepted:

April 152020

Doi Number

10.37950/ijd.v2i1.35

\begin{abstract}
Conflict is one of the social phenomena that continues to exist in human life. Conflict usually comes from several aspects such as social change, differences in authority (authority), differences in interests and cultural differences. Because Indonesia is a very diverse country of pluralism it is a variety of ethnic and ethnic diversity. Such diversity and diversity can lead to ethnic conflict. Simply put, this article will analyze the causes of conflict between ethnic Dayak and Madura in West Kalimantan, especially in Samalantan sub-district, how the impact will be caused by the conflict between Dayak ethnic with Madura in Samalantan, and also the attitude or action of the government to the conflict. In writing this scientific paper the author uses the method of literature study that comes from books or various articles that according to the author can support this writing. And based on the author's analysis of the conflict between Dayak ethnic with Madura in Samalantan. Apparently the conflict in Samalantan has happened more than ten times, can not be added with certainty. The background of the conflict occurred because of the lack of government role in providing information to the Madura who will migrate to the island of Borneo about the customs, culture, and things that are not liked by the Dayaks when incoming by ethnic immigrants. The government's action to resolve the conflict is to facilitate the meeting between the two Dayak ethnic groups with Madura. But the impact of the conflict is certainly there are positive and negative, the positive Madurese become independent, and the Dayak negatively arise casualties.
\end{abstract}

Keywords : conflict, ethnicity, dayak madura, samalantan 
Volume 2 Issue 1, April 2020

http:/ /hk-publishing.id/ijd-demos

\begin{abstract}
Abstrak
Konflik merupakan salah satu fenomena sosial yang terus ada dalam kehidupan manusia. Konflik biasanya bersumber dari beberapa aspek seperti adanya perubahan sosial, perbedaan kewenangan (otoritas), perbedaan kepentingan dan perbedaan kultural. Karena indonesia merupakan sebuah negara yang sangat majemuk dari kemajemukan itu adalah adanya berbagai keragaman etnis dan suku bangsa. Dari keberagaman dan perbedaan tersebut dapat menimbulkan terjadinya konflik etnis. Secara sederhana, tulisan ini akan menganalisa penyebab terjadinya konflik antara etnis dayak dan madura di kalimantan barat khususnya di kecamatan samalantan, bagaimana dampak yang akan ditimbulkan dari konflik antar etnis Dayak dengan Madura di Samalantan, serta bagaimana sikap ataupun tindakan pemerintah terhadap konflik tersebut. Dalam penulisan karya ilmiah ini penulis menggunakan metode studi pustaka yang bersumber dari buku-buku atau berbagai artikel yang menurut penulis dapat mendukung penulisan ini. Dan berdasarkan hasil analisa penulis terhadap konflik antar etnis Dayak dengan Madura di Samalantan. Ternyata konflik di Samalantan sudah terjadi lebih dari sepuluh kali, tidak bisa dijumlahkan dengan pasti. Adapun latar belakang dari konflik tersebut terjadi karena kurang adanya peran pemerintah dalam memberi informasi terhadap orang Madura yang akan bertransmigrasi ke pulau Kalimantan mengenai adat istiadat, budaya, serta hal-hal yang tidak disukai oleh orang-orang Dayak ketika di datangi oleh etnis pendatang. Tindakan pemerintah dalam mengatasi konflik adalah dengan memfasilitasi pertemuan antara kedua etnis Dayak dengan Madura. Tetapi dampak yang di timbulkan dari konflik itu tentu ada yang positif dan negatif, positifnya orang Madura menjadi mandiri, serta orang Dayak negatifnya timbul korban jiwa
\end{abstract}

Kata kunci : konflik, etnis, dayak madura, samalantan

\title{
Pendahuluan
}

Indonesia merupakan sebuah negara besar yang masyarakatnya terdiri dari berbagai macam etnis dengan ragam bahasa dan budayanya dan juga yang sangat majemuk dilihat dari berbagai dimensi. Satu sisi mengatakan keberagaman tersebut dapat dijadikan kekuatan dan potensi kekayaan bagi bangsa Indonesia. Namun dalam sejarahnya, kelompok etnis tertentu biasanya mendiami atau tinggal di sebuah pulau, sehingga sebuah pulau di wilayah nusantara sering kali identik dengan etnis tertentu. Pulau kalimantan. Misalnya, identik dengan etnis Dayak (walau di dalamnya terdapat sekian banyak subetnik, dan karena itu konsep Dayak sesungguhnya hanyalah semacam sebutan umum untuk penduduk asli kalimantan).

Dalam kehidupan masyarakat terdapat beragam adat istiadat, dan kepentingan, sehingga muncul berbagai variasi baru dalam bentuk budaya, baik hasil budaya dari penciptaan budaya baru maupun kebiasaan masyarakat. Ada nilai positif dan negatif dari keanekaragaman yang ada di Indonesia. Sisi positifnya 
adalah Indonesia akan penuh dengan keragaman budaya. Sisi negatif dengan adanya keberagaman tersebut dapat pula memicu terjadinya gesekan-gesekan yang bisa mengarah pada konflik. Konflik bisa terjadi apabila ada kesalah pahaman penafsiran antara individu-individu atau beberapa kelompok masyarakat yang memiliki latar belakang budaya yang berbeda. Hal tersebut akan berdampak dalam kehidupan masyarakat baik dalam aspek sosial, budaya, hukum, ekonomi, maupun kependudukan.

Berlangsungnya konflik tidak hanya sekedar untuk mempertahankan hidup dan eksistensi. Akan tetapi juga bertujuan pada taraf pembinasaan eksistensi lawan. Karena konflik merupakan bagian yang selalu ada dalam masyarakat. Konflik hanya akan hilang bersamaan dengan berakhirnya eksistensi suatu masyarakat. Konflik juga sering dianggap sebagai bentuk perjuangan untuk memperoleh hal-hal yang langka seperti nilai, status, kekuasaan, otoritas, dan sebagainya. Dimana tujuan dari mereka yang berkonflik itu tidak hanya untuk memperoleh keuntungan tetapi juga untuk menundukan saingannya. Konflik sering juga lebih dipandang sebagai sesuatu yang bersifat negatif, karena orang melihat dampak konflik yang menggunakan cara-cara kekerasan seperti bentrokan antar kelompok, perang, dan sebagainya. Dampak tersebut pula umumnya berupa kerusakan dan kerugian material maupun non material. Konflik memiliki dampak yang traumatik. Dan dianggap mengganggu stabilitas atau keseimbangan yang diharapkan masyarakat pada umumnya.

Dengan pandangan sebagaimana tersebut diatas, maka banyak orang yang beranggapan bahwa sebenarnya konflik itu seharusnya di hindari karena dianggap sebagai sesuatu yang tidak baik. Karena biasanya faktor pemicu dari konflik tersebut bisa jadi di picu oleh permasalahan biasa dan dapat di selesaikan dengan jalan dama dan kekurangannya.

Konflik biasanya bersumber dari beberapa aspek seperti adanya perubahan sosial, perbedaan kewenangan, perbedaan kepentingan dan perbedaan kultural. Jadi, dapat dikatakan bahwa sebenarnya konflik bukanlah masalah yang perlu di khawatirkan. Jadi, selama kita pahami tentang penyebab dan cara mengendalikannya. Tetapi perlu diketahui diantara semua jenis konflik, konflik yang paling berbahaya adalah konflik antar etnis. Seperti konflik yang terjadi antara etnis dayak dan etnis madura di samalantan kalimantan barat.

secara geografis, wilayah kalimantan barat berbatasan dengan provinsi kalimantan tengah dan kalimantan timur, yang sebagian besar wilayahnya merupakan tanah datar dan sebagian merupakan daerah berbukit dan bergunung. Di samping orang dayak yang merupakan penduduk asli, ada pula keturunan pendatang yang mendiami wilayah tersebut, yang terdiri dari orang melayu, katholik, budha, serta hindu.

Keanekaragaman penduduk yang tinggal dikalimantan barat yang ditandai oleh kemajemukan etnis, agama, budaya, asal-usul daerah tersebut tidak selamanya berdampak positif,dalam arti kerjasama, persatuan, atau integrasi, tetapi juga dapat menimbulkan bentuk persaingan, pertentangan atau konflik sosial. Bahkan menurut Arkanudin (2005:122) dalam masyarkat yang terdiri dari berbagai etnis, kecenderungan akan terjadi hubungan yang tidak harmonis sulit untuk dihindari.

Perbincangan tentang konflik etnis dalam perpolitikan nasional kembali aktual. Pertikaian etnis dikalimantan barat yang telah menelan korban harta dan 
jiwa, mengingatkan kita pada peristiwa kaum jahiliyah, dimana telah terjadi pembunuhan antar manusia. Nyawa manusia seakan tak bernilai akibat egoisme dan kepentingan kelompok. Di Indonesia sendiri telah muncul budaya komunalisme dan kanibalisme. Ini merupakan suatu peradaban yang memilukan dikala indonesia memasuki era reformasi sebagai manusia yang beragama dan beradab.

adapun fenomena yang sekaligus fakta yang sama bahwa konflik terjadi relatif sering dan selalu berulang. Dalam kurun waktu 50 sampai 6o tahun terakhir. Telah terjadi 10 sampai dengan 12 kali konflik. Hal ini berarti bahwa dalam kurun waktu 4-5 tahun, rata-rata telah terjadi beberapa konflik (Bahari, 2005). Dari sekian banyak konflik antar etnis di kalimantan barat, konflik antar etnis dayak dengan madura lah yang paling mencekam dan menakutkan, karena selalu memakan korban yang sangat banyak dan meninggalkan kesan traumatik bagi semua pihak.

Sejarah konflik antar etnis khususnya antara dayak dengan madura, di kalimantan barat merupakan suatu sejarah yang panjang dan terus berulang-ulang dan cenderung semakin membesar, baik dilihat dari sisi kuantitas dan kualitasnya. Ini mengindikasikan resolusi yang dilakukan tidak berhasil. Resolusi yang gagal dapat disebabkan oleh tidak diketahuinya secara tuntas akar penyebab konflik tersebut. Istilah dari Collins (2003, dalam Bahari, 2005) konflik sosial yang berkepanjangan itu disebabkan oleh tidak adanya informasi yang cukup dan mendalam tentang konflik sosial itu sendiri. Ketidakmampuan pemerintah untuk mengatasi konflik itu dapat disebabkan oleh keterbatasan pengetahuan dan keterampilan mereka dalam menangani konflik, tetapi memang di sengaja oleh karena adanya berbagai kepentingan lain yang tersembunyi di balik konflik itu, karena tidak terselesaikan dengan baik, maka potensi konflik akan tetap ada bukan bahkan bisa menjadi besar. Konflik yang berulang menandakan resolusi yang dilakukan sebelumnya belum menyentuk akar penyebab konflik tersebut. Gagalnya resolusi konflik itu membawa dampak pada terjadinya konflik terbuka yang berkepanjangan dan menimbulkan apa yang disebut oleh Nobel dengan kejahatan yaitu perang (Nobel dalam Bahari, 2005).

Konflik bernuansa etnis antara dayak dan madura telah terjadi beberapa kali di kalimantan barat. Dengan kronologis konflik berdarah dalam rentan waktu tahun 1950 hingga 2001. Seperti ketika pada tahun 1979 khususnya di samalantan, kabupaten sambas kalimantan barat. Telah terjadi pembuhunan atas sidik (dayak) yang tewas disabet clurit Asmadin asal madura. Kejadian yang menewaskan sidik itu segera memicu perkelahian massal antara etnis dayak dan etnis madura yang menewaskan 21 orang dan puluhan rumah terbakar.

Fenomena diatas, muncul pertanyaan dan analisis berbagai perspektif (ideologi, politik, sosial. Budaya dan ekonomi) tentang penyebab terjadinya konflik etnis. Dalam perspektif politik, muncul anggapan bahwa terjadinya konflik itu akibat permainan elit politik sebagai upaya untuk men-delegtimasi upaya pemerintahan pasca tumbangnya rezim orde baru, dengan kata lain berkobarnya berbagai konflik dan kerusuhan sosial yang terjadi di Indonesia. Sikap politik diatas bertentangan dengan HAM. Akibatnya fatal, yaitu pemerintah gagal membangun konsolidasi demokrasi dan ketidak adilan sehingga mengakibatkan luka yang dalam dihati rakyat atau konflik etnis ini memang terjadi murni antar etnis karena faktor ekonomi, politik, kecemburuan sosial dan faktor lainnya. 
Volume 2 Issue 1, April 2020

http:/ / hk-publishing.id/ijd-demos

\section{Kerangka Teori}

\section{Tinjauan Tentang Teori Konflik}

Teori konflik adalah teori yang memandang bahwa perubahan sosial tidak terjadi melalui proses penyesuaian nilai-nilai yang membawa perubahan, tetapi terjadi akibat adanya konflik yang menghasilkan kompromi-kompromi yang berbeda dengan kondisi semula. Teori ini didasarkan pada pemilikan sarana-sarana produksi sebagai unsur pokok emisahan kelas masyarakat.

Konflik sosial selalu berawal dari perbedaan pandangan, langkah dan pemahaman dan benturan di antara-kepentingan antar kelompok maupun antar individu. Konflik merupakan salah satu proses sosial disasosiatif, sebab proses ini berakibat timbulnya perpecahan antar-elemen sosial. Akan tetapi, kembali pada sifat konflik ini sendiri, dimana positif dan negatifnya gejala konflik akan sangat tergantung pada bagaimana konflik ini dikelola atau diarahkan (Hikmawan, 2020). Dalam kehidupan masyarakat yang majemuk tidak dipungkiri banyak hal yang potensial menimbulkan adanya konflik sosial, yaitu beberapa yang menjadi penyebabnya adalah (Elly 2011:557-558):

Menguatnya etnosentrisme kelompok. Etnosentrisme berasal dari kata etnos yang artinya suku, sedangkan sentrisme berasal dari kata sentral yang artinya titik pusat. Dengan demikian, etnosentrisme memiliki arti perasaan kelompok di mana kelompok merasa dirinya paling baik, paling benar, paling hebat sehingga mengukur kelompok lain selalu merujuk kepada kelompoknya. Secara sosiologis, etnosentrisme dapat diartikan sebagai gejala dimana kelompok sosial selalu mengunakan indikator mengukur unsur-unsur kebudayaan kelompok lain selalu merujuk kepada kelompoknya

Stereotip terhadap kelompok seperti: anggapan bahwa orang Batak kasar, orang Madura memiliki budaya kekerasan karena seringnya terjadi peristiwa carok. Biasanya stereotip seperti ini sering kali menimbulkan kesalahpahaman antar kelompok sosial. Ketersinggungan atas opini akan lebel kelompok dengan lebellebel yang bersifat ejekan seperti ini akan menimbulkan sifat ketersinggungan kelompok yang akhirnya menggugah tersulutnya konflik sosial.

Hubungan antara penduduk asli dengan penduduk pendatang : seperti yang pernah terjadi di Sambas, Kalimantan Barat antara etnis Madura dan Dayak. Selain konflik Sambas juga terdapat konflik Sampit yaitu konflik antar etnis Jawa dan Dayak dimana konflik diawali oleh sikap-sikap tertentu yang menimbulkan ketersinnggungan antarpihak, antara penduduk pendatang dan penduduk asli

\section{Konflik Etnis}

Konflik antar etnis adalah sebuah konflik bersenjata antar kelompok etnis. Konflik tersebut kontras dengan perang saudara dimana hanya sebuah negara atau kelompok tunggal yang bertarung satu sama lain. Jadi, konflik etnis juga seringkali bernuansa kekerasan. Tetapi konflik etnis juga bisa tidak dengan kekerasan. Namun biasanya konflik etnis bernuansa kekerasan dan pasti akan menimbulkan jatuhnya korban (Hikmawan, 2017a). Etnis atau suku bangsa itu biasanya memiliki berbagai kebudayaan yang berbeda satu dengan yang lainnya. Tapi, sesungguhnya sesuatu 
yang dianggap baik atau sakral dari suku tertentu itu tidak di anggap baik bagi suku yang lain. Dan perbedaan etnis tersebut dapat menimbulkan terjadinya konflik antar etnis (Hikmawan, 2017a).

Konflik kecil misalnya dapat berubah menjadi konflik besar apabila pernah terjadi kasus serupa di masa lalu yang kemudian terulang kembali dimana etnis yang terlibat konflik tersebut sama dengan peristiwa sebelumnya. Kebanyakan, informasi yang berkembang di kalangan masyarakat hanya menyuguhkan suku etnis yang bertikai daripada menelisik kejadian sebenarnya. Inilah yang dapat membuat sebuah konflik etnis bertambah besar (Hikmawan, 2017b).

Namun setidaknya ada enam hal yang dapat melatarbelakangi terjadinya konflik etnis disebuah tempat. Enam hal tersebut yaitu : kepentingan yang sama diantara beberapa pihak, perebutan sumber daya, terbatasnya sumber daya yang, kategori atau identitas yang berbeda, prasangka atau diskriminasi, dan ketidakjelasan aturan (ketidak adilan). Akibatnya bisa karena memang sumber daya manusianya yang terbatas. Adapun dalam arti pendidikannya juga kurang atau tingkat ekonominya rendah. Karena seharusnya dari masing-masing kepala daerah yang ada di wilayah konflik tersebut harus tegas membuat atau merealisasikan kebijakan ketika terjadi sebuah konflik antar etnis.

Dalam konteks Indonesia sendiri, sangat sudah tidak asing lagi mendengar terjadinya konflik antar etnis. Sebenarnya akar dari konflik ini adalah adanya keterbelakangan dari masyarakat di wilayah konflik tersebut (Simamora, Hamid, \& Hikmawan, 2019). Karena Indonesia mempunyai beragam suku, agama, ras, dan golongan membuat Indonesia sebagai bangsa yang rawan konflik. Peristiwa akibat dari terjadinya konflik setelah lengsernya otoritas orde baru dan lahirnya era reformasi yaitu salah satunya peristiwa konflik antara dayak-madura dikalimantan barat.

\section{Metode Penelitian}

Dalam penulisan karya ilmiah ini, untuk mendapatkan data yang diperlukan. Tulisan ini menggunakan metode studi pustaka. Metode Studi Pustaka adalah penelitian yang dilakukan oleh peneliti dengan mengumpulkan sejumlah bukubuku, majalah, yang berkenaan dengan masalah dan tujuan penelitian. Buku tersebut dianggap sebagai sumber data yang akan diolah dan dianalisis (Danial A.R, 2009:80). Penelitian yang dilakukan dengan cara menelaah dan membandingkan sumber kepustakaan untuk memperoleh data yang bersifat teoritis. Disamping itu dengan menggunakan studi pustaka penulis dapat memperoleh informasi tentang teknik-teknik penelitian yang diharapkan, sehingga pekerjaan peneliti tidak merupakan duplikasi.

Metode studi pustaka atau literatur ini dilakukan dengan cara mendapatkan data atau informasi tertulis yang bersumber dari buku-buku dan berbagai artikel yang menurut penulis dapat mendukung penulisan ini. Menurut John W. Best, penulisan karya ilmiah ini juga menggunakan sumber primer yang merupakan cerita atau catatan para saksi mata, dari data yang diperoleh tersebut oleh saksi mata atau pengamat dan juga bisa catatan saksi mata yang mengalami peristiwa. Sebenarnya data-data dan catatan-catatan mengenai konflik antar etnis Dayak dan 
Volume 2 Issue 1, April 2020

http://hk-publishing.id/ijd-demos

etnis Madura memang ada, tetapi hanya didokumentasikan oleh Pihak Kepolisian, dan ketika kasus sudah dianggap selesai maka data atau dokumen tersebut dalam jangka 5 (lima) tahun harus di musnahkan (dibakar).

\section{Hasil dan Diskusi}

\section{Resistensi Etnis terhadap Kekuasaan}

Sebagai negeri yang sarat dengan beban kultural, Indonesia sesungguhnya sangat berhasil menata dirinya sendiri untuk masing-masing etnis menjadi bagian dari kesatuan yang lebih luas. Persoalan yang melahirkan pertikaian/konflik itu lebih disebabkan oleh persoalan yang ada diluar etnis itu sendiri. Sejalan dengan itu, dapat dilihat tiga kondisi dasar yang menentukan hubungan antaretnis di Indonesia (Hikmawan, 2017a). Pertama, faktor keseimbangan hubungan antaretnis yang berubah. Keseimabnagn hubungan antaretnis memang tidak mungkin dicapai karena posisi ekonomi dan politik satu etnis dengan etnis lain sejak awal memang sudah berbeda, masalah muncul ketika perbedaan itu semakin mencolok dan melahirkan ketimpangan secara meluas dalam menguasaan sumber daya. Etnis pendatang seringkali menjadi dominan dalam penguasaan sumber daya walaupun dari sudut jumlah mereka tergolong minoritas (Hikmawan, 2017b). Ketimpangan meluas kedalam ketimpangan akses politik yang menyebabkan lahirnya dominasi suatu etnis (Hikmawan, 2017b). Dua hal yang berbahaya adalah ketika kelompok etnis dominan mendapatkan kedudukan dikursi pemerintahan, dan ketika kesadaran tentang batas-batas budaya mulai muncul. Etnis setempat mula sadar bahwa wilayah itu merupakan tanah air mereka yang mulai dijajah oleh orang luar.

Dalam proses ini kelompok etnis yang memiliki kesadaran kelompok dan identitas yang lebih besar dan mulai memperhitungkan batas-batas etnisitasnya. Seperti penolakan masyarakat Dayak terhadap Madura dan menuntut mereka untuk meninggalkan wilayah Dayak (Kompas 26/1/2001). Pertikaian itu disebebkan karena pemerintah telah gagal memainkan peran yang gagal mengendalikan dominasi etnis dalam penguasaan sumber daya yang seharusnya sangat perlu dilakukan melalui serangkaian kebijakan (Hikmawan, 2020). Dan proses standarisasi yang dilakukan dalam kehidupan sosial-politik telah melampaui batas-batas toleransi kultural karena bukan lagi merupakan proses penyadaran etnis sebagai bagian dari satu kesatuan sistem sosial yang lebih besar dengan identitas bersama, tetapi sudah sampai pada peningkatan eksistensi dan identitas kultural etnis. Nasionalisasi yang berlebihan telah menafikan eksistensi nilai-nilai dan pranata sosial loka. Tokoh adat telah digantikan dengan sistem organisasi yang standar yang dibentuk pemerintah, sehingga melahirkan tekanan kultural yang dahsyat (Abdullah 2001)

Melemahnya ikatan-ikatan tradisional dan kredibilitas tokoh akibat campur tangan pemerintah yang terlalu besar. Jadi, kelompok sosial dalam masyarakat Indonesia telah terganggu akibat berbagai kebijakan yang sentralistis (Hikmawan, 2017b). Karena kebijakan Orde Baru secara sistematis telah menggeser posisi dan peran tokoh-tokoh lokal. Ulama, Ketua Adat, dan tokoh informal yang sesungguhnya menempati posisi yang sangat penting sebagai 'juru bicara' bagi kedua belah pihak (bagi rakyat dan pemerintah). Hilangnya tokoh kharismatis yang menjadi panutan disisi lain, telah menyebabkan tekanan dan keresahan secara 
meluas. Sementara tokoh formal tidak memiliki pengaruh yang luas karena ia tidak mengakar dalam sistem sosial setempat. Setiap pertikaian yang muncul tidak dapat lagi dikendalikan karena pemimpin kharismatis dan mekanisme pengendaliannya tidak lagi tersedia. Itu hanya sebuah romantisme saja jika sekarang kita mengharapkan pertikaian dapat diselesaikan oleh tokoh dari dua etnis yang bertikai karena posisi mereka tidak lagi terlegitimasi secara kultural dan struktural. Selama lebih dari 32 tahun hak-haknya telah di geser dan di alihan kepada pemimpin formal melalui rangkaian undang-undang dan putusan-putusan yang dibuat oleh pemerintah. Pertikaian itu bukan semata-mata persoalan perbedaan etnis, tetapi sudah lebih mengakar pada kesalahan kita dalam mengelola perbedaan dan konflik itu sendiri disatu sisi dan dalam mengelola kepentingan publik di lain sisi (Hikmawan, 2020). Penegasan faktor peningkatan kepentingan identitas kelompok sebagai faktor sentral dama pertikaian etnis (H.Starr 1999).

\section{Etnis Dayak dengan Budaya Kekerasannya}

Sebutan dayak adalah sebuah kategori etnis yang disepakati sebagai penduduk asli kalimantan. Mereka yang disebut dayak sesungguhnya sangat heterogen karena terdiri dari komunitas-komunitas kecil yang memiliki logat bahasa berbeda dengan tradisi adatnya tidak persis sama (Mudiyono, 1994:211). Oleh karena itu, terdapat berbagai nama dari suku dayak sebagai golongan atau kelompok seketurunan (Nihin, 1994:234). Rousseau (1990) memperkirakan jumlah subsuku dayak dikalimantan berkisar antara 300 sampai 450-an. Kelompok etnis dayak memiliki bahasa tersendiri dan merupakan kelompok etnis yang terbesar. Di Kalimantan Barat itu sendiri jumlah etnis dayak mencapai 41,00\% dari jumlah penduduk Kalimantan Barat, yaitu 3.954.300 jiwa (Kalbar Dalam Angka, 2000).

Kelompok etnis dayak telah menghuni pulau kalimantan ribuan tahun yang lalu. Etnis dayak ini mengklaim dirinya sebagai penduduk asli kalimantan. Etnis dayak ini juga memiliki sikap hidup yang sangat sederhana, monoton, kurang kreatif dan tidak berani mengambil inisiatif lebih banyak menunggu, pasrah, menerima nasib, banyak mengalah, mengharapkan belas kasihan orang lain, lugu, dan polos. Cepat puas, kurang atau sedikit jiwa bertarung atau kompetisi. Melihat sesuatunya secara lurus saja tanpa memandang liku-likunya (Alif, 1993:34). Keadaan ini menyebabkan orang dayak selalu tertinggal dalam segala aspek kehidupan. Ketertinggalan orang dayak, menurut Alif (1993:37) disebabkan oleh faktor latar belakang hidup orang dayak adalah agraris tradisional yang selalu terikat dengan alam sekitarnya dan segelintir orang dayak terjun ke bidang bisnin tidak cukup dibekali pengetahuan manajemen, sehingga banyak yang pailit. Dan lebih penting lagi latar belakang orang dayak dalam sejarahnya dapat dimengerti bahwa orang dayak kurang berminat dan kurang berbakat untuk terjun kedunia bisnis. Jadi, mata pencaharian yang digeluti dari etnis dayak yaitu bertani. Namun dengan berjalannya waktu diantara etnis dayak sebagian telah menjadi pegawai negeri ataupun karyawan swasta.

Pada masa Orde Lama, orang dayak menguasai kepemimpinan provinsi dan mendominasi memimpin beberapa Kabupaten di Kalimantan Barat. Keadaan ini dapat dimaklumi karena kedekatan pemimpin dayak ketika itu dengan pemerintahan Soekarno. Jadi ketika rezim Soekarno jatuh, semua pemimpin dayak ketika itu dihabisi dengan dalih terlibat Partai Komunis Indonesia. Pada masa orde 
baru, orang dayak mengalami marginalisasi secara sistematis, rumah-rumah panjang yang memiliki multifungsi dalam kehidupan orang dayak dihancurkan dengan dalih sanitasi jelek dan kawasan adat mereka pun sering di srobot tanpa kompromi dengan alasan tanah negara dan yang paling tragis adalah ketika diberlakukannya UU No 5 Tahun 1974 dan 1979 tentang pemerintahan desa, dimana segala sesuatu harus seragam. Adanya perlakuan terhadap kehidupan dayak yang tidak adil ini membuat karakter-karakter kekerasan dalam bentuk dendam. Mereka mudah emosi, mudah panas hanya dipicu oleh persoalan yang sangat sepele, dengan mudah membangkitkan kemarahan komunal. Padahal budaya mengayau ini sudah lebih dari 100 tahun hilang.

\section{Etnis Madura dengan Budaya Kekerasannya}

Etnis madura yang ada di Kalimantan Barat adalah yang berasal dari Bangkalan Madura akhir abad XIX, dan baru menetap di daerah ini sekitar tahun 1920, dengan maksud untuk mencari lahan-lahan yang lebih subur dibandingkan dengan daerah asalnya di pulau Madura (Achadiyat, 1989:51). Berdasarkan penelitian Sudagung (1983), kedatangan orang madura ke Kalimantan Barat berlangsung dengan satu periode.

Periode pertama, terjadi menjelang dan setelah kemerdekaan yaitu sekitar tahun 1942-1950. Pada periode ini adalah masa peralihan, ekonomi turut tidak menentu sehingga orang-orang madura cenderung mengikuti jejak awal untuk mengadu nasib dan mau bekerja apa saja, tergantung wilayah yang mereka tuju. Kedatangan orang madura secara besar-besaran di Kalimantan Barat ini terjadi antara tahun 1980 hingga 1989. Bahkan pada masa Orde Baru keberadaan orang madura sangat berperan dalam politik di Kalimantan Barat, sebagai anggota DPRD tingkat I dan II dan bahkan ada yang menjabat sebagai Bupati pada salah satu Kabupaten di Kalimantan Barat.

Dalam kehidupan sosial, orang-orang madura sangat terikat dengan warga sesama masyarakatnya walaupun banyak kerabat, yang penting bagi mereka adalah sedaerah asal. Karakter dan kepribadian etnis ini berani, kuat secara fisik, kerja keras, ulet, percaya diri, sendiri, hemat, tidak memilih jenis pekerjaan, bersedia diupah rendah dan patuh pada pimpinan tradisional dan agama (Alqadrie, 1999:51). Disamping karakter dan kepribadian yang positif, terdapat beberapa karakter miring dan berbagai perilaku negatif lainnya seperti keras kepala, mau menang sendiri, cenderung memaksakan kehendak, sombong, meyelesaikan masalah dengan kekerasan, membangga-banggakan tradisi dan budaya sendiri, kurang tertarik pada tradisi dan adat istiadat setempat, berkepribadian kurang seimbang serta gugup (Alqadrie, 1999:51). Dengan karakter tersebut etnis ini cenderung tidak mematuhi prinsip budaya dimana bumi di pijak di situ langit dijunjung.

Pada masa sebelum terjadi konflik etnis di Kalimantan Barat, kelompok etnis Madura tidak hanya terdapat di kota Pontianak. tetapi menyebar di berbagai desa seperti Sambas, Bengkayang, Sanggau, Sintang, Ketapang, dan juga terdapat di kampung monterado, sendoren, margamulia. Etnis madura ini sendiri juga terdapat di kecamatan samalantan kabupaten sambas.

\section{Menulusuri Penyebab Terjadinya Konflik Etnis Dayak dan Madura di Samalantan}


Tidak ada suatu masyarakat dimana pun di dunia ini yang tidak mengalami konflik. Konflik yang di alami oleh masyarakat dalam kehidupan sosialnya, perbedaannya hanyalah terletak pada intensitasnya dan cakupan wilayahnya. Ada konflik yang berupa persaingan dan bertentangan biasa saja, yang melibatkan warga masyarakat dalam jumlah yang relatif kecil, akan tetapi ada juga konflik yang melibatkan masyarakat dalam jumlah yang besar. Pertemuan etnis Dayak dan Etnis Madura yang berbeda latar belakang kehidupan sosial bdaya pasa suatu tempat sangat potensial menimbulkan konflik.

Menurut Bahari (2005), latar belakang dugaan dan penyebab terjadinya konflik, khususnya antara etnis Dayak dan Madura di Samalantan Kalimantan Barat bermacam-macam. Misalnya, pihak pemerintah termasuk aparat keamanan dn menduga terjadinya konflik sosial dengan kekerasan antar etnis itu disebabkan oleh adanya dalang yang menggunakan isu SARA sebagai pemicunya. Tujuannya adalah untuk mengacaukan stabilitas politik nasional dan mengganggu dinamika pembangunan. Selain itu akar terjadinya konflik antara etnis dayak dan madura di Samalantan Kalimantan barat adalah masalah budaya. Adapun konflik yang terjadi anatara etnis Dayak dan Madura di Samalantan ini sangat sepele. Konflik ini berlangsung selama lima hari. Asal muasal konflik tersebut pada tanggal 8 November 1979 itu, ketika seorang warga dari etnis madura sedang merumput untuk makanan sapi di sebuah pematang sawah di kampung Sendoren. Tak berapa lama lewatlah seorang warga dari etnis dayak dan menegur seorang warga dari etnis madura untuk berhati-hati mengambil rumputnya karena khawatir terkena padi sekitarnya. Tetapi teguran tersebut di telinga seorang warga dari etnis madura ini seperti suatu penghinaan dan akhirnya perang mulutpun terjadi. Seorang warga dari etnis madura tersebut berhenti menyabit rumput dan segara pulang kerumah untuk mengambil calok parang panjang yang biasa di pakai orang madura, lalu ia mendatangi rumah seorang warga dari etnis dayak tersebut akhirnya seorang warga dari etnis madura yang membawa calok tersebut menusuk perut seorang warga dari etnis dayak dan akhirnya seorang etnis dayak tersebut meninggal. Kabar tewasnya seorang dari etnis dayak tersebut menyebar dari kampung ke kampung. Kelompok dari etnis dayak mencari seorang warga dari etnis madura yang telah membunuh seorang warga dari etnis dayak itu. Dan akhirnya konflik tersebut tidak dapat dihindarkan terjadilah perkelahian massal diberbagai kampung anatar kedua kelompok itu. Tidak hanya perang melawan calok, api pun ikut bicara. Konflik yang berlangsung selama lima hari ini termasuk konflik yang sangat sepele menyebabkan kurang dari 20 orang tewas, 2 luka berat, termasuk seorang anak kecil dan lima puluh rumah terbakar. Konflik sepele lainnya yaitu kasus pencurian ikan di bubu (penangkap ikan) yang pemiliknya orang dayak warga Samalantan, yang mencuri ikan tersebut adalah orang madura dan tertangap basah oleh pemilik bubu ikan tersebut, ketika ditegur oleh sipemilik bubu, orang madura tersinggung dan langsung membacok pemilik bubu ikan tersebut dengan menggunakan celurit (senjata khas madura).

Konflik antara etnis dayak dan madura di Salamantan disebabkan juga oleh faktor cemburu sosial dari segi ekonomi yang dimana Kalimantan Barat mempunyai prospek ekonomi yang cerah. Potensi itu dibangun bersama berikan kesempatan kepada penduduk setempat untuk ikut serta, memang sumberdaya manusianya belum memadai untuk masuk proyek-proyek raksasa, tetapi minimal penduduk 
setempat ikut merasakan apa yang diusahakan ditanah mereka. Pertikaian yang berakhir dengan konflik yang terjadi di Samalantan adalah faktor ekonomi yang dari masyarakat orang-orang madura adalah warga pendatang dengan tujuan memperbaiki derajat hidupnya yang awalnya sudah ingin menjadi lebih baik lagi. Maka dari itu mereka menjadi pekerja keras, dan akhirnya mereka telah menikmati hasilnya yitu banyak yang menjadi berkecukupan bahkan sangat lauak, karenanya orang-orang pribumi atau orang dayak tersebut menjadi iri terhadap orang madura, dan didasarkan dengan perasaan iri maka hal-hal kecil itu menjadi hal utama pemicu terjadinya konflik.

Adapun faktor lain yang menyebabkan konflik yang terjadi antara etnis dayak dan madura di Salamantan yaitu salah satunya alasan marjinalisasi yang dimana pada masa awal Orde Baru terjadi pembersihan birokrasi di unsur-unsur yang dituduh "kiri" yang kebetulan kebanyakn terdiri dari orang-orang dayak. Bahkan orang-orang madura sesungguhnya lebih merupakan simbolisasi "kekuatan luar" yang dianggap menggusur orang-orang dayak. Orang-orang madura merupakan representasi yang paling dekat dan konkrit dari kekuatan eksternal yang meminggirkan posisi orang-orang dayak. Adapun penjelasan yang paling umum atas kekerasan adalah pengusiran dan marjinalisasi masyarakat dayal secara perlahan menimbulkan akumulasi frustasi dan akhirnya meledak dengan target menyerang orang-orang madura.an lebih dari dua dasa warsa pemerintah Indonesia telah mengijinkan perusahaan penebangan kayu lapis dan perkebunan komersial untuk menggunakan tanah yang oleh orang dayak di anggap sebagai tanah mereka. Padahal sejalan dengan meningkatnya marjinalisasi orang dayak secara ekonomi, mereka juga kehilangan basis politik. Beberapa putera dayak pernah menduduki jabatan Gubernur dan Bupati, namun setelah masa Orde Barunya Soeharto berkuasa pada awal tahun 1966 orang dayak yang disingkirkan dari pemerintahan karena di tuduh sangat kekiri-kirian.

faktor yang menyebabkan terjadinya konflik antara etnis dayak dan madura di Salamantan yaitu disebabkan oleh alasan politik disamping faktor-faktor penting seperti faktor budaya dan sosial-ekonomi, skala pertikaian yang lebih besar dari pertikaian sebelumnya hanya mungkin bila ada intervensi dari pihak ketiga. Beberapa lapisan masyarakat dan oragnisasi di tuduh mengundang kerusuhan termasuk di dalamnya pegawai pemerintah, para pemimpin dayak maupun madura dan partai politik. Mereka yang berpendapat adanya pihak ketiga dengan mengingat peristiwa pada tahun 1967, sewaktu Tentara menghasut oarng-orang dayak berperang melawan etnis cina di Kalimantan Barat dan pemerintah waktu itu mengatakan bahwa peristiwa itu terjadi secara spontan tetapi sebenarnya tidak demikian. Sejauh yang diketahui di Samalantan itu sudah lama ditinggali oleh orang-orang Madura, Cina dan masih banyak yang lain, ketika terjadi konflik yang dijakdikan sebagai penanggung jawabnya adalah orang Dayak, karena orang Dyak yang mempunyai masalah dengan orang Madura maka tidak ada sanggahan lagi dari pihak orang Dayak jika di tuduh sebagai pelaku konflik, dengan begitu orangorang pendayang lainnya mendapat keuntungan bisa mengganti posisi kursi pemerintahan yang diduduki oleh orang-orang Madura yang unsur-unsur politiknya ada tetapi tidak banyak.

Jadi, semua latar belakang penyebab terjadinya konflik antara etnis Dayak dan Etnis Madura rata-rata mempunyai satu sudut pandang yang sama di kalangan 
Volume 2 Issue 1, April 2020

http://hk-publishing.id/ijd-demos

masyarakat umum di Kalimantan Barat khususnya Samalantan yaitu oleh karena perseturuan yang sudah lama dan masih saja tetap terulang kelmabli walaupun sudah berkali-kali didamainkan oleh berbagai pihak, baik dari pegawai pemerintah , tokoh-tokoh masyarakat, tokoh-tokoh adat, bahkan kepolisian, tetapi konflik tersebut masih saja terulang kembali.

\section{Dampak dari Konflik Etnis Dayak dan Madura di Samalantan}

Dampak yang ditimbulkan dari konflik antara etnis Dayak dan Madura di Samalantan Kalimantan Barat yaitu terjadinya dampak negatif antara kedua suku yang bertikai tentu membuat hubungan yang pada awalnya baik-baik saja akan menjadi tidak baik, hal tersebut dirasakan sampai sekarang, yang dimana bahwa setiap ada orang Madura masuk ke pemukiman orang Dayak untuk berdagang maka setiap warga akan sangat curiga dengan gerak-gerik perlakuannya, itupun jika ada yang berani masuk, karena pada umumnya orang-orang Madura tidak ada lagi yang berani masuk ke pemukiman orang Dayak dikarenakan adanya trauma. Karena dampak negatif dari konflik tersebut telah menelan korban yang kurang lebih berlangsung selama tiga bulan setelah terjadinya konflik pasti ada korban yang meninggal dan luka-luka.

Dampak negatif lainnya seperti kerugian dari segi ekonomi. Pasca terjadi konflik antara etnis Dayak dengan etnis Madura di Kalimantan Barat, khususnya di Samalantan telah mengalami krisis ekonomi yang buruk bahkan untuk sumber makanan saja susdah didapat, ditambah lagi keadaan sedang tidak baik. Maka tidak heran saat terjadi konflik, banyak masyarakat Dayak yang memanfaatkan keadaan dengan mengambil hak milik orang Madura yang kemudian diakuinya menjadi hak miliknya. Tetapi hal tersebut tidak benar adanya karena memanfaatkan keadaan orang yang sedang susah, tapi hal yang seperti itu menjadi tidak asing lagi bagi masyarakat Samalantan. Karena pada saat itu kondisi ekonomi juga sedang lemah, maka wajar saja jika terjadi pengakuan atas harta orang-orang madura.

Selain adanya dampak negatif dari konflik tersebut adapula dampak positif yang terjadi antara konflik etnis Dayak dan etnis Madura di Samalantan. Seperti orang-orang Dayak merasa aman setelah puluhan tahun hidup berdampingan bersama pendatang dari pulau Madura karena orang Dayak sudah terlalu sering mengalami konflik dengan penduduk pendatang tersebut, banyak masalah-masalah sepele yang dapat menjadi pemicu konflik yang berakhir dengan luka-luka serius bahkan sampai kematian. Akhir dari konflik tersebut adanya fase kecil, fase sedang dan fase besar. Memang ada yang dinyatakan fase besar tapi masyarakat Samalantan masih penuh dengan toleransinya sehingga masih bisa menerima orangorang Madura untuk tetap tinggal di Kecamatan Samalantan, tetapi puncak kesabaran sudah habis ketika terjadinya konflik tersebut, orang-orang Dayak yang ada di Samalantan tidak lagi bisa hidup bersama-sama dengan orang Madura Karena merasa sudah tidak aman. Konflik berakhir dan hanya meinggalkan sisa-sisa rumah dan aset-aset orang Madura tanpa pemiliknya lagi yaitu orang Madura, dengan begitu sudah bebaslah tanah Samalantan dari orang-orang Madura, tapi tidak dengan oarng-orang Madura yang sudah menjadi penduduk asli Samalantan terutama menikah dengan orang Dayak, karena yang seperti itu sudah dianggap bukan orang Madura lagi tetapi di anggap sudah menjadi orang Dayak. Sampai saat ini penduduk Samalantan sudah tidak pernah mengeluh lagi dengan keamanan, 
sudah tidak ada lagi yang ketakutan pulag kerumah masing-masing pada malam hari, karena waktu masih ada orang Madura seringkali terjadi perampokanperampokan dijalan ketika pengguna jalan tersebut hanya berjalan sendiri. Sejak berakhirnya konflik di Samalantan berubah menjadi signifkan. Setelah kepergian orang-orang Madura dari Samalantan suasana menjadi aman dan tenang.

Dampak positif yang terjadi dari konflik tersebut juga menjadikan orangorang pribumi atau orang-orang dari etnis Dayak menjabati di kursi pmerintahan. Dalam kursi pemerintahan yang ada di Kalimantan Barat orang Dayak masih sangat kurang jumlahnya untuk mewakili sebagian besar penduduk pribumi yaitu etnis Dayak di kursi pemerintahan, baik ditingkat Camat, Bupati apalagi Gubernur sangatlah kecil jumlahnya. Dengan terjadinya konflik antara etnis Dayak dan Madura maka kursi yang sebelumnya di duduki oleh orang adura menjadi pindah tempat kepada orang Dayak. Dengan begitu, konflik tersebut memberi peluang untuk tampilnya orang-orang pribumi di kursi pemerintahan, maka tidaklah heran jika sekarang ini banyak pula etnis Dayak yang menduduki tempat yang sebelumnya belum pernah disentuh oleh orang Dayak.

Setelah membahas beberapa dampak dari terjadinya konflik antara etnis Dayak dengan ettnis Madura di Kalimantan Barat, khususnya di Samalantan, banyak pembahasan mengenai bagaimana dampak yang di derita masyarakat Kalimanan Barat setelah terjadi konflik yang telah memakan banyak korban. Dan para tokoh adat meminta supaya di adakan "nyaru sumangat" yang dimana artinya itu adalah semacam upacara adat yang dengan tujuan antara lain mengemalikan kententraman dan persaudaraan di Kalimantan Barat. Prosesi "nyaru sumangat" tersebut dilaksanakan di Rumah Adat Dayak yaitu rumah panjang yang berlokasi di Samalantan, dipilihnya Samalantan sebagai tempat prosesi "nyaru sumangat" juga mempunyai alasan yang jelas, adalah karena di Samalantan merupakan salah satu tempat yang penduduk Maduranya lumayan banyak, dan di Samalantan juga merupakan salah satu tempat dimana kerusuhan antara etnis Dayak dan etnis Madura seringkali terjadi bukan hanya satu kali melainkan berkali-kali, berbagai usaha perdamaian telah dilakukan tetapi tetap saja terjadi lagi. Jadi, melihat alasan tersebut para Tetua Adat Dayak mengusulkan untuk mengadakan upacara "nyaru sumangat" di Samalantan.

\section{Sikap Pemerintah terhadap Konflik Etnis Dayak dan Madura di Samalantan}

Konflik tentulah bukan sesuatu yang diingkan dan terjadi oleh siapapun di muka bumi ini, karena apapun itu alasannya pasti akan merugikan kedua belah pihak yang terlibat konflik tersebut. Jadi, sebenarnya konflik terjadi karena beberapa latar belakang, dan akhir dari konflik pasti menyisakan luka yang dalam dari pihak manapun. Konflik sebenarnya terjadi sangat spontan dan tidak dapat diketahui kapan akan di mulai konflik itu, maka sangat wajar jika banyak pihak yang bertanya-tanya kapan dan dimana serta apa penyebab terjadinya konflik.

Adapun beberapa peran pemerintah untuk menanggapi konflik di Samalantan Kalimantan Barat yaitu yang pertama dengan mengadakaan musyawarah. Sebelum terjadinya konflik yang lebih luas pemerintah setidaknya telah mengambil tindakan dan kebijakan untuk mendamaikan kedua belah pihak yang bertikai antara pihak orang Dayak dan orang Madura di Samalantan, salah satu cara dengan mengadakan musyawarah. Karena pertikaian bermula tentu tidak 
langsung secara besar-besaran, tapi tentu hanya antara individu yang satu dengan individu yang lain tentu saja masih bisa ditangani oleh pihak pemerintah dan tokohtokoh adat dari orang Dayak. Lebih lagi khususnya di Samalantan jika ada yang bertikai dan diurus oleh para tokoh-tokoh adat, maka pelaku konflik yang dinyatakan bersalah oleh para tokoh-tokoh adat tersebut wajib mentaati hukuman yang diberikan . jenis hukuman yang diberikan di Samalantan khususnya secara umum di Kalimantan Barat di sebut dengan "bayar adat" yang dimana sejenis penggantian dari benda-benda yang harus di serahkan kepada korban konflik. Jadi, jika seseorang telah terbukti bersalah maka harus membayar sebuah tempayan besar, tapi untuk sekarang tempayan besar susah untuk di dapat bahkan untuk membeli saja sudah jarang ditemukan, maka cara lain untuk membayar tempayan tersebut adalah membayar dengan mata uang tetapi dengan seharga tempayan tersebut. Untuk membayar dengan mata uangpun harus membuat pesta ditempat kediaman korban konflik dengan mengorbankan ayam, anjing dan babi sebagai simbol darah yang keluar saat pertikaian terganti dengan darah binatang piaraan tersebut. Membuat pesta semacam itu mempunyai maksud untuk agar pelaku pertikaian dapat merasakan betapa pentingnya sifat penyabar dan rendah hati terhadap sesama, sehingga dalam menyelesaikan konflik tidak harus menggunakan kekerasan apalagi sampai menghilangkan nyawa seseorang, dalam adat Dayak jika ada pertikaian yang sampai mengeluarkan darah maka seluruh anggota pelaku pertikaian harus bertanggung jawab. Sebenarnya, musyawarah yang difasilitasi oleh pemerintah dalam penanganan konflik kecil sudah sangat membantu, tetapi tidak bisa bertahan lama untuk timbulnya masalah baru dari kelompok Madura lainnya yang ada di Samalantan, tapi bagi masyarakat Samalantan musyawarah memang merupakan jalan tengah untuk menyelesaikan konflik. Tapi, terkadang sudah tidak bisa ditangani oleh pemerintah itu karena konflik sudah terlalu luas.

Yang kedua untuk menanggapi konflik tersebut dengan membuat perjanjian antara orang Dayak dengan orang Madura, sebenarnya banyak kesepakatan yang telah disepakati waktu di adakan nya perjanjian tapi karena terlalu banyak, maka hanya sedikit yang dipatuhi oleh kedua belah pihak. Walaupun sudah dibuat beberapa perjanjian tetap saja tidak bisa membuat keadaan menjadi aman seutuhnya, tetapi masih tetap saja masih terjadi konflik.

Adapun peran pemerintah untuk menangani konflik konflik yang terjadi antara etnis Dayak dengan etnis Madura dengan mendatangkan TNI dari Pulau Jawa yang melihat situasi konflik yang semakin parah dan kacau pemerintah dari Provinsi meminta bantuan dari pemerintah pusat untuk membantu menyelesaikan konflik yang terjadi di Kalimantan Barat, akhirnya pemerintah pusat yang diminta oleh Komnas HAM mengirimkan TNI atau semacamnya yang mengurus konflik kurang lebih 1000 orang banyaknya yang didatangkan dan disebar luaskan kebebrapa tempat, target utama yang ingin di amankan oleh para TNI Aadalah Samalantan dan masih banyak tempat lainnya yang menjadi tempat pemukiman orang Madura.

Setelah melalui beberapa kebijakan diatas untuk menanggapi konflik tersebut yang memang dapat di katakan lebih efektif dalam penyelesaian konflik yang sudah menjadi permasalahan besar bagi masyarakat Samalantan. maka dari itu, pemerintah mengambil kebijakan supaya didirikan tugu perdamaian dan di setujui oleh semua pihak maka didirikanlah tugu perdamaian tersebut dengan tujuan tidak 
ada lagi dendam antara pendatang dengan penduduk peribumi lebih khusus lagi antara orang Dayak dengan orang Madura, tatepi tidak hanya dua etnis tersebut (Dayak-Madura) yang menjadi isi di tugu perdamaian tersebut melainkan semua jenis etnis yang berdomilisi di Samalantan seperti suku Melayu, suku Jawa, suku Cina, suku Sunda, suku Bugis. Jadi pada proses pembuatan tugu perdamaian itu semua jenis etnis ikut terlibat, bahkan pada saat peresmian tugu perdamaian semua perwakilan dari etnis semuanya turut hadir guan menghormati dan menghargai didirikannya tugu perdamaian.

Pada saat pembuatan tugu perdamaian tersebut semuanya lancar-lancar saja tidak ada masalah baik dari bahan material maupun tenaga kerja, tugu tersbeut dibuat tidak mewah tetapi hanya berupa tiang-tiang segi empat yang hampir sama. Dan Bhineka Tunggal Ika berada paling atas dengan tulisan yang sangat besar yaitu "berbeda-beda tapi tetap satu" itulah pengertian daripada Bhineka Tunggal Ika yang merupakan salah satu isi daripada tugu perdamaian yang ada di Samalantan dan ditengah tiang-tiang tersebut dibuat patung garuda yang berisi sila-sila yang pertama ketuhanan yang maha esa, kemanusiaan yang adil dan beradab, persatuan Indonesia, kerakyatan yang dipimpin oleh hikmat kebijaksanaan dalam permusyawaratan perwakilan, keadilan sosial bagi seluruh rakyat Indonesia. serta sebelah kanan tugu tersebut terdapat isi dari sumpah pemuda yang menyatakan, kami pemuda Republik Indonesia pemegang hari depan rakyat kita bersifat ksatriatoleransi-musyawarah-setiakawan dan bertanggung jawab, kami pemuda Republik Indonesia setia dan taat kepada sumpah pemuda 28 Oktober 1928, kami pemuda Republik Indonesia tetap meneruskan cita-cita Proklamasi kemerdekaan 17 Agustus 1945, kamu pemuda Republik Indonesia adalah pelopor persatuan Bangsa Indonesia, kamu pemuda Republik Bangsa Indonesia menjunjung tinggi agama dan keyakinan kita masing-masing serta sedia berkorban untuk keluhuran Negara dan Bangsa Indonesia. dan sebelah kiri dan belakang terdapat relief-relief semua suku yang menjadi penghuni tetap kecamatan Samalantan dan relief tersebut sedang bergandengan tangan merupakan salah satu contoh yang disampaikan oleh pemerintah guna meminimalisir terjadinya konflik di Samalantan.

Jadi, sebenarnya inti didirikannya tugu perdamaian itu mempunyai tujuan untuk menjaga perdamaian antara etnis Dayak dengan etnis Madura dan lainnya. Bahwa wakil-wakil orang Dayak dan Madura menyetujui pernyataan dengan mengutuk kekerasan yang terjadi dan komitmen mereka dengan perjanjian damai, tidak menyediakan tempt bagi pendatang baru yang jelas, melarang membawa senjata dan menghormati tradisi setempat. Tradisi "bayar adat" diadakan pesta berupa makan-makan bersama karena untuk menjaga adat istiadat dan budaya di Samalantan dimana setiap pembangunan baik apapun itu jalan, rumah, tempat ibadah dan lainnya pasti ada pesta untuk adat istiadat. Ketika pesta telah selesai diadakan doa bersama untuk menghormati apa yang telah dibuat bersama-sama yang berbentuk tugu tersebut, setelah berdoa ada sesi pemotongan balom udara tiga buah yang mempunyai maksud dan tujuan semoga apa yang menjadi doa dan harapan orang Dayak dan Madura untuk berdamai bisa naik ke atas langit dan dikabulkan oleh Tuhan yang Maha Kuasa.

Berakhirnya konflik yang terjadi antara etnis Dayak dengan etnis Madura merupakan tragedi yang tidak bisa dilupakan begitu saja, dan bagaimana cara pemerintah untuk menyelaikan konflik tersebut supaya tidak ada lagi timbul 
dendam di lain waktu dari orang dari orang Dayak dengan orang Madura atau dengan etnis lainnya. Perjanjian adalah kebijakan yang diambil pemerintah di kecamatan Samalantan setelah berakhrinya konflik dan beberapa perjanjiannya yaitu orang amdura pergi dari kecamatan Samalantan. Setelah seringkali terlibat konflik orang Dayak dengan orang Madura di Samalantan, masyarakat Samalantan membuat pernyataan dan pernyataan tersebut sebagai berikut "semua orang Madura yang tinggal di kecamatan Samalantan harus pergi, karena masyarakat Samalantan sudah merasa tidak aman hidup berdampingan dengan orang Madura". Dan orang madura boleh ke Samalantan tapi tidak untuk menetap lagi, karena ternyata orang Dayak masih memiliki rasa toleransi yang tinggi terhadap orangorang Madura khususnya yang punya niatan baik. Sampai saat ini masih sering di jumpai orang-orang Madura di Samalantan walaupun tidak sebanyak dulu sebelum terjadi konflik. Mereka datang ke Samalantan bukan untuk kembali menetap melainkan untuk berbisnis, dengan catatan mereka tidak boleh tinggal lama apalagi menetap di Samalantan, karena orang-orang Dayak sudah tidak bisa hidup berdampingan dengan orang-orang Madura.

\section{Kesimpulan}

Beberapa kasus konflik etnis yang terjadi di beberapa tempat di tanah air, telah menyadarkan kita wawasan kebangsaan guna mencegah terjadinya proses disintegrasi. Kasus konflik etnis di Kalimantan Barat menjadi contoh dari banyak kejadian hampir serupa yang melanda Indonesia. Dengan membicarakan konflik etnis di Kalimantan sendiri khususnya sudah pasti langsung tersirat di benak pikiran bahwa pasti konflik yang terjadi yaitu antara etnis Dayak dengan etnis Madura, sebenarnya hal tersebut sudah tidak asing lagi bagi salah satu wilayah di Kalimantan Barat yaitu terutama di Kecamatan Salamantan, karena wilayah tersebut merupakan salah satu tempat dimana kerusuhan/pertikaian antar etnis Dayak dengan etnis Madura sering kali terjadi. Konflik yang terjadi di Samalantan tersebut dapat di katakan sudah terjadi kurang lebih 17 kali dengan berupa konflik fase kecil, fase sedang, dan fase besar.

Orang Dayak sendiri merupakan suatu etnis yang sangat suka akan kebersamaan, kejujuran, dan penuh dengan toleransi, jadi, terlihat sudah berpuluhpuluh tahun orang madura hidup di Kalimantan dan mereka menerimanya dengan lapang dada. Tetapi ketika itu keamanan mereka terusik dengan begitu mereka akan marah dan menjadi jahat bahkan lebih jahat dari sebelumnya. Etnis Dayak sangat mudah marah ketika merasa terncam itu disebebkan karena pada masa Orde Baru karena kedekatan pemimpin dayak itu dengan pemerintahan Soekarno. Jadi, ketika rezim Soekarno jatuh semua pemimpin orang dayak dihabisi dan orang dayak mengalami marginalisasi adanya perlakuan tersebut tidak adil bagi kehidupan orang dayak ini membuat karakter-karakter kekerasan dalam bentuk dendam. Mereka mudah emosi, mudah panas hanya dipicu oleh persoalan yang sangat sepele, dengan mudah membangkitkan kemarahan. Sedangkan orang Madura itu sendiri merupakan suatu etnis yang suka bekerja keras.

Ketika terjadi konflik banyak hal yang diusahakan pemerintah guna mendamaikan kedua belah pihak yaitu dari etnis Dayak dan etnis Madura seperti 
menjadi penengah, memfasilitasi pertemuan dengan kedua belah pihak dengan membuat perjanjian, bahkan yang lebih hebatnya lagi dengan membuat tugu perdamaian, tetapi hal tersebut hanya di atas kertas saja. Karena orang madura sebagian besar tidak suka menepati janji dan seringkali tidak menetapi janji yang telah di setujui.

Jadi, dampak konflik yang terjadi berulang kali itu menyebabkan banyaknya korban jiwa baik dari pihak orang Madura maupun dari pihak orang Dayak. hilangnya tempat tinggal orang-orang Madura, terjadi perusakan rumah-rumah. Sekarang sudah tidak ada lagi orang madura walaupun masih terdapat orang Madura di Samalantan tetapi mereka bukan menetap untuk tinggal melainkan untuk berbisnis. Hal itu terjadi karena orang Madura sendiri yang menjadikan kekerasan sebagai alat untuk menyelesaikan masalah pribadinya dengan orang dari etnis Dayak.

\section{Referensi}

Arkanudin (2006). Menelusuri akar konflik antar etnis di kalimantan barat. Vol. 7 No.2, Desember 2006

Bambang Suwondo. (1979). Sejarah Kebangkitan Nasional Daerah Kalimantan Barat. Jakarta: Departmen Pendidikan dan Kebudayaan Pusat Penelitian Sejarah dan Budaya Proyek Penelitian dan Pencatatan Kebudayaan Daerah

Bambang Wibisono. (2001). Penggunaan Kalimat Negatif dalam Bahasa Madura. Jakarta: Pusat Bahasa Departmen Pendidikan Nasional.

Chatarina Pancer Istiyani. (2008). Memahami Peta Keberagaman Subsuku dan Bahasa Dayak di Kalimantan Barat. Pontianak: Institut Dayakologi.

Danial, SR., Endang dan Wasriah, Nana. (2009). Metode Penulisan Karya Ilmiah. Bandung: Laboratorium PKn UPI

Irwan Abdullah (2001). Kebijakan Negara Dalam Pemecahan Konflik Etnis

Giring. (2004). Citra Orang Madura di Mata Orang Dayak Kanayatn. Yogyakarta: Galang Press.

Hendro Suroyo Sudagung. (2001). Mengurai Pertikaian Etnis Migrasi Swakarsa Etnis Madura ke Kalimantan Barat. Tanpa Tempat: Institut Studi Arus Informasi bekerjasama dengan Yayasan Adikarya Ikapi dan The Ford Foundation.

Hikmawan, M. D. (2017a). Pluralisme Demokrasi Politik di Indonesia. Journal of Governance, 2(2), 223-247.

https:/ / doi.org/http:/ / dx.doi.org/10.31506/jog.v2i2.2678

Hikmawan, M. D. (2017b). Politik Perbedaan: Minnoritas dalam Implementasi

Kebijakan. Journal of Indonesian Public Administration and Governance Studies (JIPAGS), 1(1), 88-98.

Hikmawan, M. D. (2020). Consensual Democracy: A Challenge for Differentiated Citizenship. International Journal of Innovation, Creativity and Change. www.ijicc.net (Vol. 11). Retrieved from www.ijicc.net 
Joko Supono, (2001). "menguak latar belakang kerusuhan disebut-sebut faktor budaya bukan merupakan faktor kunci dalam konflik etnis madura-dayak. Apa penyebabnya?" Dalam Nurartha Situmorang (Ed). Sisi gelap kalimantan barat perseturuan Etnis Dayak-Madura 1997, Pontianak: Institut Dayakologi hlm. 364,

Miall, Hugh, Rombutsham, Oliv-er, dan Woodhouse, Tom, Resolusi Damai Konflik Konternporer: Mencegah, Mengelola, dan Mengubah Konflik Bersumber Politik, Sosial, Agama, dan Ras, Rajawali Press, Jakarta, 2000.

Setiadi, Elly M. dan Usman Kolip. 2011 Pengantar Sosiologi. Jakarta: Kencana Preneda Media Group

Simamora, A. R., Hamid, A., \& Hikmawan, M. D. (2019). Diskriminasi Terhadap Kelompok Minoritas Jemaat Ahmadiyah Indonesia (JAI) di Tangerang Selatan. International Journal of Demos, 1(1), 19-37. Retrieved from http:/ /hkpublishing.id/ijd-demos 